\title{
For an Efficient Complaints Management System for Banks: A Conceptual Framework and an Exploratory Study
}

\author{
Wissem Hakiri \\ Faculty of Economics and Management of Tunis Marketing Department / Research Unit ERMA - \\ Tunisia
}

\begin{abstract}
This research reviews a concept which is still relatively less considered by retail banks: managing complaints. A review of literature will highlight the importance of managing complaints by banks in a CRM approach. Then, analyzing the contents of real complaints in 4 different banks allowed us to form a database. This database allows researchers and bankers alike a better view of banking complaints and will give us the opportunity to suggest concrete recommendations on how to improve complaints management.
\end{abstract}

Key words: Banking, services marketing, CRM, complaints management.

\section{Introduction}

Strategies for managing the effects of service incidents on satisfaction, intention to complain .... have been studied to restore exchange balances between a customer, potentially disappointed by a flawed service, and the "offending" firm. Faulty services and their management may be seen as an exchange situation in which players evaluate their profits and losses.

In this context, complaint management may be considered a key, even an essential, variable within a service-based relationship. A dissatisfied customer is likely to cut off the relationship or act in a negative way which may damage the firm. Moreover, it is admitted that seeking a new customer is generally more costly than preserving an existing one (Fornell $\mathrm{C}$. and wernerfelt B., 1987).

Retail banks' faulty services tend to negatively affect service quality and consequently customers satisfaction. This state of affairs tends to intensify the need for an efficient complaints management system (Sabadie W. and Prim-AllazI., 2006).

This paper aims at examining content of real customer complaints of 4 retail banks. Data analysis allowed us to classify retained complaints by topics and order of importance. This study attempts to provide a database for retail banks so as to better manage customer complaints and lead a better customer complaint management system.

\section{Relational Marketing at the Centre of Banking Services}

Given the limits of marketing management tools often used in transactional marketing, this concept has found progressively its way into the hands of researchers and practitioners. Studies showed that the relational marketing approach is perfectly adapted to the service sector; retail banking being no exception (Des Garets V., Paquerot M. et Sueur I., 2009).

Copyright (C) 2012 Wissem Hakiri. This is an open access article distributed under the Creative Commons Attribution License unported 3.0, which permits unrestricted use, distribution, and reproduction in any medium, provided that original work is properly cited. Contact author: Wissem Hakiri E-mail: hakiriw@gmail.com 
The very nature of services, conditions of their supply and consumption naturally make the interactions between contact personnel and customers very strategic (Eiglier P. and Langeard E., 1987). Services are characterized among other things by their intangibility and heterogeneity and by customer involvement in servuction (Eiglier P. and Langeard E., 1987). Intangibility notably results in complicating the evaluation of what the service provider is offering and even sometimes during consumption of what is being offered (Sabadie W. and Prim-AllazI., 2003)

According to Des Garets et al. (2009), interpersonal relationships are particularly important in a context where service quality is difficult to evaluate and risk is perceived high by customers. Then, relational marketing is perfectly adapted to banking sector. Banks have already called for some tools to go through CRM (Des Garets V., Paquerot M. and Sueur I., 2009)

\section{For an Efficient CRM, a Good Complaints Management is Needed}

Des Garets et al. (2009) showed that many tools have been used by banks to establish a customer relationship in view of «attracting, maintaining and reinforcing customer relationship" thus imposing the merits of relational marketing. Zablah et al., (2004) assume that CRM is often considered as the visible part of relational marketing and is its implementation phase. However, customer involvement in servuction and the importance of interpersonal relationships explain as well the numerous incidents that likely take place (Sabadie W., 2000).The service provider should then prevent incidents and make available an efficient complaint management system (Sabadie W. and PrimAllazI., 2003).

Firm-wise, incidents management integrates itself within a relational view of exchanges as it raises the issue of the necessary efforts needed to compensate for the loss incurred by the customer on the one hand and maintain and even promote the relationship on the other hand (Sabadie
W. and Prim-AllazI., 2005). Complaint management is a research field relatively recent and offers new research venues. It is integrated within the larger view of customer relationship management (Sabadie W. and Prim-AllazI., 2005)

\section{Complaints Management: Its Role During Disruption of a Banking Service Relationship}

\section{Disrupting a Relationship: From Dissatisfaction to Complaints}

According to Perrien et al. (1995), marketing research often privileges factors underlying and reinforcing relationships and focuses less on factors explaining its disruption. While explaining reasons of relationships disruptions within banking sector, roles of accounts directors and contact personnel, these same authors showed that relationship weakness is the primary reason, of which "complaints management" is one component (Perrien J, Paradis S. and Banting P.M, 1995). Customer dissatisfaction may be revealed through complaints. Complaints, when expressed, are strong and revealing signals for the firm, leaving available an ultimate chance to maintain relationship with customers, if it is able to understand and manage complaints (Crié D. and Ladwein R., 1998).

However, it is worth noting that dissatisfaction is a necessary motive yet often insufficient for a complaining behaviour. It is the triggering factor of the process. However, it has been shown that there is a relationship between dissatisfaction intensity and complaining (Crié D., 2001).

\section{Complaints or Complaining Behaviour}

Chébat J.C., and Slusarczyk W., (2005) suggest that the process of complaining implies "transactions" between the dissatisfied customer and service provider. These exchanges may lead to compensation mechanisms that meet more or less customers' expectations. Other authors chose to focus on presenting the concept of complaining behaviour. Jacoby. J. And 
Jaccard. J.J., (1981) define complaining behaviour as «an action undertaken by an individual in the form of a communication about a negative element of a product (service), either to the firm or to a third party". According to Day R.L. and ali (1981), a complaining behaviour is a result of a given consumption act, following which the consumer is faced with an experience leading to a higher degree of dissatisfaction, strong enough to be neither psychologically appreciated nor forgotten". Singh J. (1988) conceives of a complaining behaviour as a process explaining that this behaviour, triggered on the emotional and sensational levels by a perceived dissatisfaction, is part of a more general context of responses to dissatisfaction. This process is twofold. The first is behavioural yet forcibly it leads to no action towards the frim. Within this latter dimension it is convenient to consider complaining behaviour. The second refers to absence of action from the part of consumer.

Other authors rather choose to consider and define the concept of "complaint". Complaints may be considered as a customer's attempt to change a situation perceived unsatisfactory. Sabadie. W and Prim-Allaz. I., (2006) assume that a complaint has three elements to it; a transmitter, the motive and the origin of the problem. These same authors point out that a complaint may be defined as a request for information, change and/or compensation from the part of a consumer towards an organisation, following dissatisfaction of which the organisation is held responsible by the customer (Sabadie W. and Prim-AllazI., 2005).

Finally, they define a complaint as a result of an explicit action by customers, or their representatives, towards the concerned organisation. It distinguishes itself from actions which are not directly oriented towards the firm (mouth-to-ear, complaints to consumers associations or courts of law, switch purchasing towards other providers ...). They judge that this distinction is important as it underlines the strategic nature of a system encouraging the collection and management of complaints (Sabadie W. and Prim-Allaz I., 2006).

However, Crié D. (2001) defines a complaint as follows : a complaint belongs to a set of responses to a perceived dissatisfaction. This author distinguishes this definition from the Anglo-Saxon concept of complaining behaviour and judges it in a very reductionist fashion. Indeed, the Anglo-Saxon view considers a complaint as being part of a set of responses to perceived dissatisfaction (Crié D., 2001). The same author conceptually defines complaining behaviour as a public behavioural response to dissatisfaction specifying that for the firm only a fraction of its responses are perceivable of which complaints.

\section{Complaints Management: Particularly Important for the Banking Sector}

Complaints management is important for the service sector as the customer finds services difficult to evaluate and as the firm finds controlling them even harder (Sabadie W. , Prim-AllazI. and Llosa S., 2006). Complaining presumes that the customer blames all or part of his/her dissatisfaction on the provider (Chébat J-C, Davidow M. and Codjovi I., 2005). The blame is the customer's own perception and it is this latter component which is decisive in managing complaints. Indeed, even if the firm is not responsible, yet the customer is convinced otherwise. $\mathrm{He} / \mathrm{she}$ expects a resolution for the problem as he/she believes that the firm is the only part responsible for it. Thus, identifying the origin of the problem as perceived by the customer is a major element of complaints management process. Indeed, the firm entertains a duality of interests: preserve future benefits related customers and improve quality of its services. Nevertheless, this reasoning presumes that the organization proposes an efficient complaint management system. 
Processing complaints through a centralized service seems to be perceived best as an insufficient need and at worst as a useless and dangerous undertaking. Responding to complaints is considered as an essential task of a customer service for two main reasons. On the one hand, it is a source of profits and on the other hand it is an opportunity to entertain a qualitypromoting policy (Rust R.T., Zahorik A.J., and Kenningham T.L, 1996).

\section{Why can an Efficient Complaint Management System Only be Beneficial for a Bank?}

Within a service relationship, human factors dominate human exchanges. It is difficult even impossible to entirely model what explains the numerous glitches that may take place (Sabadie W. , Prim-AllazI. and Llosa S., 2006). The service provider, being completely unable to prevent these incidents, should provide an efficient complaint management system (Rust R.T., Zahorik A.J., and Kenningham T.L, 1996)

Problems should be resolved at the level of daily interactions between contact personnel and customers, which counts as one of the main services specificities (Mayaux F. and Revat R., 1994). Thus, a service involving competent contact personnel, in charge of "Complaints Management", is needed. This should be valued and deserves more attention by researchers and practitioners alike. Then, success of a service and preservation of loyalty rest on the social interactions between contact personnel and customers. More particularly, they rest on a good complaints management, a crucial element in maintaining bank performance. Complaints management offers real opportunities to retain customers having problems with the service provider, provided that they are satisfied by how their complaints are processed (Hart C., Heskett J., Sasser W. E., 1990).

The paradox of complaints management rests on the hypothesis according to which following an incident a dissatisfied customer may be more satisfied and more loyal than a customer with no incident provided the firm proposes an adequate management of his/her complaint (Sabadie W. and Prim-AllazI., 2005).

Even if switching to other banks is not simple, the sector's officials grew aware of the need to establish a true relationship with customers in view of limiting the opportunistic nature of exchanges and retaining these exchanges for a long time. Several tools have been proposed to promote exchange occasions that give the impression that a relational approach has been adopted by banks.

\section{Which Complaints Management for Banks?}

\section{Methodology}

Following the literature review, we insist that a qualitative study of customers' complaints and complaints management is of order. Indeed, the aim of this study is to obtain a better comprehension of complaints management within banking sector, a process which is less recognised, conducting a qualitative study. However, we are convinced that such a study, based on observations and content analysis, is more rewarding than a simple study based on questionnaires. This analysis would allow us the opportunity to suggest some concrete proposals to help banks better manage complaints.

\section{Data and Sample}

As a reminder, an analysed complaint is that which is object of statements, oral or written, of a dissatisfaction formulated by a customer towards offered products or services.

Note that the present study does not rely on scenarios or intentions of behaviour but on an analysis of real complaints collected from 4 retail banks taken from different departments as shown in the following table (Table 1).

These studied real complaints have been collected from customers of these 4 banks, mostly individual customers. 
Table 1: Number of Analysed Complaints by Bank

\begin{tabular}{|l|l|l|l|}
\hline Banks & $\begin{array}{l}\text { Is there a specific Complaint } \\
\text { Management service? }\end{array}$ & Complaints taken from & $\begin{array}{l}\text { Total number of } \\
\text { analysed } \\
\text { complaints during } \\
\text { the study period }\end{array}$ \\
\hline Bank A & $\begin{array}{l}\text { Yes } \\
\text { (service animation quality) }\end{array}$ & $\begin{array}{l}\text { "Complaints and customer } \\
\text { relationship" service }+ \\
\text { customer care }\end{array}$ & 330 \\
\hline Bank B & No & $\begin{array}{l}\text { Monetary service }+ \\
\text { customer care }\end{array}$ & 204 \\
\hline Bank C & No & $\begin{array}{l}\text { Agency Principal } \\
\text { (Director) }\end{array}$ & 93 \\
\hline Bank D & No & $\begin{array}{l}\text { Accounting service }+ \\
\text { customer care }\end{array}$ & 275 \\
\hline \multicolumn{2}{|l|}{ Complaints } & \multicolumn{2}{|l}{ Total = 902 } \\
\hline
\end{tabular}

\section{Interpretation of Results}

The content analysis of 902 real complaints of the banks under study allowed us to extract 7 topics and 34 sub-topics. The list is not exhaustive as it is limited to services targeted by this study. The results generated for each topic and sub-topic a set of responses to be taken by banks as a database (see Appendix). These responses relate to degree of complaints importance, resolution possibility, solutions, delays and some propositions. The set of this information in this database allows us to report the following results:

- A theme analysis of the set of complaints revealed 7 themes: accounting functioning problems, complaints on reception and service, complaints about online service, complaints on credits, complaints on cards and ATMs, cheques problems and others.

- A second theme analysis has been conducted and revealed 34 sub-themes.

- Among the 34 sub-themes, we noticed that 25 are settled complaints and 9 are unsettled complaints.

- These complaints differ in their degree of importance ranging from an ordinary complaint to an urgent complaint and of which important complaints are a majority.
- Complaints settlement time varies between «an on-the-spot settlement » to «two-week settlement» and improving complaints management pours into reducing settlement time.

- Among the most-frequently settled we can mention those related to cards and ATMs. This kind of complaints varies but settled in almost all cases.

- As for unsettled complaints, we can mention those related to account billing fees, rates dates, tax payment, interest rates, notification of an overdraft cheque -..

- In this case, the constraint is generally « legal ». Put differently, rules apply. For this kind of complaints, customers should be explained the measures undertaken.

- Some complaints may be avoided even cleared if more attention is taken, like: double fees, accounting errors, hard-toread statements ....

- Some propositions are suggested in the database for each sub-theme and we note that reducing settlement time is the most important. Indeed, this component may even differentiate banks where services are similar and imitation is growing fast. 


\section{Conclusion}

Managing a complaint is not a simple task. Nowadays, firms seek all means to reach improving their services quality. This latter cannot be done only trough resolving problems with their customers, mainly settling complaints. Indeed, complaints management in an organization integrates itself within this initiative and aims at continually improving quality of products and services offered to customers. Whatever the size of this organization, it should promote the development of a complaints processing policy. Furthermore, customers' satisfaction is a strategic objective of a Complaints Management policy.

Particularly, within the service sector a complaint is another chance for the firm to improve quality of its service and win again customer's trust. We note that customers with problems and who complain remain loyal to the firm than those who remain silent about their dissatisfaction.

However, a justified complaint can only be a signal of a misunderstanding. A complaining customer seeks that his/her complaint is taken into consideration by the bank. Then, a customer who has been listened to and understood may become the best spokesman on behalf of the bank and accordingly the bank cannot ignore the importance of settling their customers' complaints.

Complaints management needs then a considerable effort to reach some results. However, the bank will accumulate many advantages as improving service quality may make its customers loyal thanks to a better complaints management. Furthermore, the main objective of complaints management is to restore a complaining customer's satisfaction in order to stabilise the relationship with the bank. This approach integrates itself within relational marketing and is an aspect of CRM.

Generally, complaints management goes through stages. First, information should be gathered. Customer care division should report directly to the adequate player known for its expertise, i.e. the service in charge. Giving the example of cards-related complaints, the monetary service is the adequate service to provide settlement. It should as well follow the complaining customer and see whether he/she is satisfied by the service given and should obtain feedback.

Second, the well-foundedness of the complaint should be examined, i..e problem source, as there are complaints which are founded and need compensation and there are complaints which are not well founded. Finally, responses should be provided to the complaining customer.

Finally, it should be noted that the effort undertaken by customer care is not often enough to restore the relationship with a complaining customer. Indeed, Boshoff C. and Leong J. (1998) show that, within their contexts of study (air transport and banking services), customers with incidents attach more importance to the fact that the firm assumes error responsibility than to the personnel ability to promptly manage the problem and apologize.

This study is first step of elaborating a "good" complaints management process for banks.

One of the limitations of this study is the field of study. This topic has never been examined in a very competitive trade context. This paper contributes to clarifying complaints management within banks through proposing a database, specific to banking complaints. It allows for a better view of banking complaints and offers a way to improve the way there are processed and a better customer relationship management.

The list of this database, though not exhaustive, represents a first conception of the topic and a first conception to be generalised and updated by other types of complaints.

This database, if digitalized, allows customer care a direct access to settling 
complaints by having the necessary information for an efficient and quick management of complaints. We can add to it a "service in charge" to be directly consulted, mainly for the case of new customer care personnel whose rotation is very frequent in banks.

\section{Recommendations and Future Research}

Complaints processing increases the firm's sales and image. If the bank examines deeply its criticism, it should perceive that it is relatively easy and less costly to predict customers' dissatisfaction and change the most furious into better ambassadors. Indeed, customers who complain are not enemies; they simply look for settling their complaints whatever the condition.

This study allowed for generating some managerial implications and recommendations of which the first relates to listening to customer. It is mandatory to cast dynamism onto customer listening. This aim may be reached through a regular personnel training on how to listen to customers increasing thus their satisfaction while respecting their demands and avoiding them access to complaints. Moreover, making listening tools available to contact personnel turns out to be important. In other words, a well trained contact personnel will need tools to better do the task like opinion records where contact personnel put down customers propositions (suggestions, complaints, encouragements ....).

The second crucial element of an initiative to improve complaints management is undoubtedly complaints settlement time. Generally, a good management of all complaints, which put customer care personnel in contact with the customer, is possible through reducing settlement time. The more the contact personnel react promptly to complaints, the more the customer is satisfied and the relationship is restored. The firm should guarantee in all cases its strength and ability to directly handle the customer to find an immediate solution.
The third point to be taken into consideration for a good banking complaints management is related to classifying complaints. All complaints are not equally important, easily settled, and similarly founded. Then, banks should classify complaints in view of managing them better. They should as well specify, for repeated complaints, the service in charge and the "ready" solution to be efficient.

The fourth implication, considered the most important as it is the most neglected relates to following-up complaints. Success of complaints management is possible through the presence of a customer followup service which insures durability and continuity of management. There are many follow-up means like following customer after settlement phase through a simple phone call or through send a customized letter to each customer to know whether or not he/she is satisfied. It is worth noting that a "thank you" note written by hand and sent to the customer is desirable as this kind of personalized approach is strongly appreciated by dissatisfied customers. In conclusion, bankers should take in charge their customers' follow-up and insure that the problem is efficiently resolved. A complaint follow-up is a sign of responsibility towards customers. In turn, the customer may have a good perception of offered services quality and bank's image. The follow-up allows knowing whether customers are satisfied by offered services and /or by the way complaints are managed. In case of satisfaction, this allows for favouring customer relation management, known as CRM. In this context, complaints follow-up is mandatory for a CRM whose objective is to create, promote and entertain permanent relationships with customers.

In case of dissatisfaction, the bank should be at its customers' disposal to satisfy them and make them loyal. This is the case of some unsettled complaints object of regulations. In this case, the bank should explain to customers the reasons for not processing their complaints in a very polite manner. Finally, complaints management is 
an efficient method to improve banking service quality and entertain durable relationships with its customers.

This study, nevertheless, has some limitations which open further future research:

- The database may be improved even enriched so as to include all types of banking complaints.

- Many firms create departments specialised in complaints management. Is it mandatory? What is the best choice: hand complaints management to customer care personnel or create a specific department for that?

- Resolving a problem requires the firm to know well dissatisfied customers and conduct advanced research of their profiles.

- Evaluating complaints management using some indicators like increase of number of complaints in time, improving settlement time, satisfied7unsatisfied complaints ratio, proportion of complaints by service .... (Mayaux F. and Revat R., 1994).

- Studying customers' expectations using complaints will be interesting.

\section{References}

Boshoff, C. \& Leong J. (1998). "Empowerment, Attribution and Apologising As Dimensions of Service Recovery, an Experimental Study," International Journal of Service Industry Management, 9, 1, 24-47.

Chébat, J.- C., Davidow, M. \& Codjovi, I. (2005). "Silent Voices, Why Some Dissatisfied Consumers Fail To Complain," Journal of Service Research, 7, 4, 1-15.

Chébat, J.- C. \& Slusarczyk, W. (2005). "How Emotions Mediate the Effects of Perceived Justice on Loyalty in Service Recovery Situations: An Empirical Study," Journal of Business Research, 58, 664-673.
Crié, D. (2001). "Un Cadre Conceptuel D'analyse Du Comportement De Réclamation," Recherche Et Applications En Marketing, 16 (1), 45-54.

Crié, D. \& Ladwein, R. (1998). "La Lettre De Réclamation Au Regard De La Théorie De L'engagement : Une Approche Empirique Dans La Vente Par Correspondance," Actes De Xivième Congrés AFM; Bordeaux.

Day Ralph, L., Grabicke, K., Schaetzle, T. \& Staubach F. (1981). "The Hidden Agenda of Consumer Complaining," Journal of Retailing, 57,3,86-106.

Des Garets, V., Paquerot, M. \& Sueur I. (2009). "L'approche Relationnelle Dans Les Banques : Mythe Ou Réalité ?," Revue Française De Gestion, 191.

Eiglier, P. \& Langeard, E. (1987). 'Servuction. Le Marketing Des Services,' Mcgraw Hill.

Fornell, C. \& Wernerfelt, B. (1987). "Defensive Marketing Strategy by Consumer Complaint Management: A Theorical Analysis," Jounral of Marketing Research, 24, November, 337-346.

Hart, C. W. L., Heskett, J. L. \& Sasser, W. E. (1990). "The Profitable Art of Service Recovery," Harvard Business Review, 68 (Jul/Aug), 148-56.

Jacoby, J. \& Jaccard, J. J. (1981). 'The Sources, Meaning and Validity of Consumer Complaining Behavior,' A Psychological Review, Journal of Retailing, 57, 3, 4-24 .

Mayaux, F. \& Revat, R. (1994). 'L'efficacité Des Services Consommateurs: Un Indicateur De Performance: Les Réponses Aux Réclamations,' Actes De Xième Congrés AFM; Paris.

Perrien, J., Paradis, S. \& Banting, P. M. (1995). 'La Rupture D'une Relation: La Perception De La Force De Vente En Milieu Bancaire,' Actes De Xiième Congrés AFM Reims.

Prim-Allazi, I. \& Sabadie, W. (2003). "Les Apports De La Théorie De La Justice Pour 
Une Meilleure Gestion Des Réclamations Clients," Actes De Ixième Congrés AFM ; Tunis.

Prim-Allazi, I. \& Sabadie, W. (2005). "Gestion Des Réclamations Et Relation De Service: Proposition D'un Modèle Intégrant Le Rôle De La Responsabilité Perçue De L'entreprise Prestataire," Actes De Xxiième Congrés AFM ; Nancy.

Prim-Allazi, I. \& Sabadie, W. (2005). "Les Apports De La Théorie De La Justice A La Gestion Des Réclamations," Décisions Marketing, Avril-Juin, 38, 7.

Rust, R. T., Zahorik, A. J. \& Kenningham, T. L. (1996). Service Marketing, New York: Harper Collins.

Sabadie, W. (2000). 'Les Apports Des Théories De La Justice Au Marketing Des Services,' Actes De La Conférence De
l'Association Française Du Marketing, Montréal, 133-147.

Sabadie, W., Prim-Allazi \& Llosa, S. (2006). "Contribution Des Eléments De Gestion Des Réclamations a La Satisfaction: Les Apports De La Théorie De La Justice," Recherche et Applications En Marketing, Sept, 21, 3, 47.

Siddiqui, M. H. \& Tripathi, S. N. (2010). "An Analytical Study of Complaining Attitudes: With Reference to the Banking Sector," Journal of Targeting, Measurement and Analysis for Marketing, 18, 2, 119-137.

Singh, J. (1988). "Consumer Complaint Intentions and Behavior: A Review and Prospect," Journal of Marketing, 52, January, 93-107.

Zablah, A. R., Bellanger, D. N. \& Johnston, W. J. (2004). "Customer Relationship Management Implementation Gaps," Journal of Personal Selling and Sales Management, 24, 279-95. 
Appendix: Banking Complaints Management Database

\begin{tabular}{|c|c|c|c|c|c|c|}
\hline & \multicolumn{4}{|c|}{ Complaints Management Database for Banks } & & \\
\hline Themes & Sub-themes & $\begin{array}{l}\text { Complaint } \\
\text { settled } \\
\text { Yes or No }\end{array}$ & Importance Degree & Solutions & $\begin{array}{l}\text { Settlement } \\
\text { Time }\end{array}$ & Comments \\
\hline \multirow{8}{*}{$\begin{array}{l}\text { Account Functioning } \\
\text { Problems }\end{array}$} & Claims about balances & Yes & Important & Checking cutomer's account & 1 week & Reduce time \\
\hline & Poor account functioning & Yes & Important & Checking by bank & \begin{tabular}{|l|}
1 to 2 \\
weeks \\
\end{tabular} & $\begin{array}{l}\text { We suggest reducing settlement } \\
\text { time }\end{array}$ \\
\hline & $\begin{array}{l}\text { Complaints about interest rates } \\
\text { for a savings account }\end{array}$ & Yes & Important & $\begin{array}{l}\text { Savings return rate is } \\
\text { variable as it is indexed on } \\
\text { the TMM rate which } \\
\text { fluctuates in the market }\end{array}$ & 1 week & $\begin{array}{l}\text { Propose a better visibility of } \\
\text { products on the brochures, on } \\
\text { the web site ... }\end{array}$ \\
\hline & $\begin{array}{l}\text { Claims about errors in debiting } \\
\text { fees, commissions and pyables }\end{array}$ & Yes & Important & $\begin{array}{l}\text { Correct error in the financial } \\
\text { statement }\end{array}$ & $\begin{array}{l}3 \text { days if } \\
\text { there is an } \\
\text { error }\end{array}$ & $\begin{array}{l}\text { Double debiting of fees is less } \\
\text { frequent but it should be } \\
\text { avoided completely }\end{array}$ \\
\hline & Account billing fees & Yes & & $\begin{array}{l}\text { Unsettled complaint, the } \\
\text { customer should pay the } \\
\text { fees }\end{array}$ & & We cannot take decisions \\
\hline & $\begin{array}{l}\text { Unreceived money transfer } \\
\text { (abroad) }\end{array}$ & Yes & Urgent & $\begin{array}{l}\text { Contact bank office if the } \\
\text { transfer is from abroad }\end{array}$ & 1 month & $\begin{array}{l}\text { suggestions : reduce transfer } \\
\text { time, insure a continuous } \\
\text { control of transfers coming from } \\
\text { abroad by creating a specialised } \\
\text { service }\end{array}$ \\
\hline & Claims about dates of rates & No & & $\begin{array}{l}\text { Unsettled complaint, it is } \\
\text { automatic }\end{array}$ & & $\begin{array}{l}\text { Only the bank can resolve the } \\
\text { problem through software }\end{array}$ \\
\hline & $\begin{array}{l}\text { Omitting an operation on } \\
\text { account statement }\end{array}$ & Yes & Urgent & $\begin{array}{l}\text { Check the bank's balance } \\
\text { sheet, correct error in the } \\
\text { financial statement }\end{array}$ & 2 days & Avoid this type of errors \\
\hline \multirow{4}{*}{$\begin{array}{l}\text { Complaints about } \\
\text { reception and service }\end{array}$} & Poor quality of service & Yes & Important & $\begin{array}{l}\text { The customer care personnel } \\
\text { answers to customers' } \\
\text { expectations }\end{array}$ & Daily & $\begin{array}{l}\text { Motivating and continously } \\
\text { training customer care } \\
\text { personnel are required }\end{array}$ \\
\hline & Request of account statements & Yes & Ordinary & \begin{tabular}{|l|}
$\begin{array}{l}\text { Respond immediately the } \\
\text { customer without delay }\end{array}$ \\
\end{tabular} & immediatel & $\begin{array}{l}\text { It is more of a request for } \\
\text { information than a complaint }\end{array}$ \\
\hline & $\begin{array}{l}\text { Lack of clarify in account } \\
\text { statements }\end{array}$ & Yes & Urgent & $\begin{array}{l}\text { As for account movements, } \\
\text { explain to customer some } \\
\text { terms belonging to banking } \\
\text { jargon }\end{array}$ & $\begin{array}{l}\text { within the } \\
\text { week }\end{array}$ & $\begin{array}{l}\text { Customer care personnel plays } \\
\text { an important role }\end{array}$ \\
\hline & $\begin{array}{l}\text { Information on products and } \\
\text { services }\end{array}$ & Yes & Ordinary & $\begin{array}{l}\text { More efforts from customer } \\
\text { care personnel, permanent } \\
\text { availability of brochures at } \\
\text { the agencies, media } \\
\text { advertising ... }\end{array}$ & & $\begin{array}{l}\text { It's important particularly in the } \\
\text { case of new products/services }\end{array}$ \\
\hline \multirow{4}{*}{$\begin{array}{l}\text { Complaints about on- } \\
\text { line service }\end{array}$} & NET Service & Yes & Important & $\begin{array}{l}\text { Improvements of the various } \\
\text { products and services are } \\
\text { placed on the bank's web } \\
\text { page }\end{array}$ & & $\begin{array}{l}\text { Present a detailed offer of } \\
\text { banking products and services, } \\
\text { Add credit siimulations and } \\
\text { demos on the web site , ,., }\end{array}$ \\
\hline & Increase of fees & No & Important & $\begin{array}{l}\text { Inform customer in advance } \\
\text { of increases in fees }\end{array}$ & & $\begin{array}{l}\text { The more the customer is } \\
\text { informed, then aware, the less } \\
\text { he/she will complain }\end{array}$ \\
\hline & $\begin{array}{l}\text { Information on the bank's web } \\
\text { site }\end{array}$ & Yes & Ordinary & \begin{tabular}{|l|} 
Customer orally complains \\
about his/her dissatisfaction \\
towards information on the \\
web site
\end{tabular} & & $\begin{array}{l}\text { Web site and its content should } \\
\text { be up dated }\end{array}$ \\
\hline & Affiliation to NET service & Yes & Important & $\begin{array}{l}\text { The bank should announce in } \\
\text { advance debiting fees on } \\
\text { services made payable }\end{array}$ & & $\begin{array}{l}\text { On-line services are important } \\
\text { and should be correctly } \\
\text { exploited }\end{array}$ \\
\hline \multirow{3}{*}{$\begin{array}{l}\text { Complaints about } \\
\text { credits }\end{array}$} & Complaints about taxes & No & & Unsettled complaint & & Taxes are mandatory \\
\hline & $\begin{array}{l}\text { Delays in granting or crediting a } \\
\text { loan }\end{array}$ & No & Important & $\begin{array}{l}\text { More personnel or } \\
\text { mechanised processing of } \\
\text { credit applications with } \\
\text { standardized applications }\end{array}$ & & $\begin{array}{l}\text { Volume of to-be-processed } \\
\text { applications is sometimes } \\
\text { higher which may lead to } \\
\text { delays, reinforcing personnel, a } \\
\text { mechanised processing system } \\
\text { and a decentralization may } \\
\text { resolve the problem }\end{array}$ \\
\hline & Interest rate & No & & $\begin{array}{l}\text { Unsettled complaint, it is the } \\
\text { law }\end{array}$ & & Current regulations \\
\hline
\end{tabular}




\begin{tabular}{|c|c|c|c|c|c|c|}
\hline \multirow{10}{*}{$\begin{array}{l}\text { cards and ATM } \\
\text { problems }\end{array}$} & Card illfunctioning & Yes & Important & $\begin{array}{l}\text { The customer informs the } \\
\text { bank by a simple remake } \\
\text { request, the agency sends } \\
\text { the complaint to monetary } \\
\text { service }\end{array}$ & $\begin{array}{l}\text { within the } \\
\text { week }\end{array}$ & $\begin{array}{l}\text { The complaint can be sent } \\
\text { through e-mail }\end{array}$ \\
\hline & $\begin{array}{l}\text { Complaints about a retained } \\
\text { card }\end{array}$ & Yes & Important & Card remake & $\max 7$ days & Reduce processing time \\
\hline & $\begin{array}{l}\text { Complaints about Payment } \\
\text { cards }\end{array}$ & Yes & Important & $\begin{array}{l}\text { Resolving the problem by } \\
\text { the monetary service }\end{array}$ & \begin{tabular}{|l|} 
Immediatel \\
y or within \\
the week
\end{tabular} & $\begin{array}{l}\text { Moving in person may help } \\
\text { resolve the complaint quickly }\end{array}$ \\
\hline & Card lost or stolen & Yes & urgent & $\begin{array}{l}\text { The customer informs } \\
\text { his/her bank, requests a loss } \\
\text { certificate, the monetary } \\
\text { service takes in charge card } \\
\text { canceling }\end{array}$ & immediatel & $\begin{array}{l}\text { In case of loss, a new pin code } \\
\text { must be delivered }\end{array}$ \\
\hline & Deficient or unreadable card & Yes & Important & Card remake & immediatel & $\begin{array}{l}\text { The monetary service is in } \\
\text { charge }\end{array}$ \\
\hline & Request of canceling a card & Yes & Ordinary & $\begin{array}{l}\text { Canceling request from the } \\
\text { part of customer and the } \\
\text { monetary service takes it in } \\
\text { charge }\end{array}$ & $\begin{array}{l}\text { Immediatel } \\
\text { yor within } \\
\text { the week }\end{array}$ & $\begin{array}{l}\text { Processing should be done } \\
\text { quickly }\end{array}$ \\
\hline & Empty ATM & Yes & Important & See ATM record and checks & $\begin{array}{l}1 \text { week to } \\
10 \text { days }\end{array}$ & $\begin{array}{l}\text { ATM should be maitained to } \\
\text { avoid technical breaks }\end{array}$ \\
\hline & Electronic unit-feeding blocked & No & Urgent & Settlement in progress & & $\begin{array}{l}\text { Insure that resolving this type of } \\
\text { complaints is done quickly }\end{array}$ \\
\hline & Incompleted withdrawal & Yes & Important & Check ATM record & 2 days & An ATM cash inventory is done \\
\hline & Electronic payments problems & Yes & Important & \begin{tabular}{|l|} 
Send a complaint to \\
monetary service and checks \\
account
\end{tabular} & $\begin{array}{l}\text { Within the } \\
\text { week }\end{array}$ & Reduce processing time \\
\hline \multirow[t]{2}{*}{ Cheques problems } & $\begin{array}{l}\text { Complaints about rejecting an } \\
\text { overdraft cheque }\end{array}$ & No & Important & $\begin{array}{l}\text { Unsettled complaint, apply } \\
\text { law }\end{array}$ & & $\begin{array}{l}\text { Notification problems are errors } \\
\text { made by customers because the } \\
\text { bank informs its customers on } \\
\text { cashing cheques, However and } \\
\text { to reduce this ttype of } \\
\text { complaints the customer should } \\
\text { be notiifed in time, then using } \\
\text { phone messaging may be } \\
\text { efficient }\end{array}$ \\
\hline & Cheque book lost or stolen & Yes & Urgent & $\begin{array}{l}\text { Inform his/her bank, a } \\
\text { request of a certificate of } \\
\text { loss from police, the bank } \\
\text { takes in charge canceling the } \\
\text { cheque, This complaint is } \\
\text { directly handled by the } \\
\text { general inspector, }\end{array}$ & $\begin{array}{l}\text { The same } \\
\text { day }\end{array}$ & $\begin{array}{l}\text { An urgent complaint given the } \\
\text { seriousness of the problem, to } \\
\text { be processed immediately }\end{array}$ \\
\hline \multirow{3}{*}{ Others } & Change of address & Yes & Ordinary & $\begin{array}{l}\text { Easy to handle complaint and } \\
\text { immediate settlement, }\end{array}$ & Immediatel & $\begin{array}{l}\text { The customer informs about } \\
\text { change in address and requests } \\
\text { an up date of his/her } \\
\text { coordinates }\end{array}$ \\
\hline & Agency location & No & Important & $\begin{array}{l}\text { The bank proposes some } \\
\text { services through internet, } \\
\text { fax, phone, e-mail, ... }\end{array}$ & & $\begin{array}{l}\text { Improve and diversify the } \\
\text { different channels of } \\
\text { communication with the } \\
\text { customer is the only alternative } \\
\text { to resolve access problem }\end{array}$ \\
\hline & Errors in salary statement & Yes & Urgent & $\begin{array}{l}\text { The bank checks with the } \\
\text { company working hours, }\end{array}$ & 1 week & Reduce settlement time \\
\hline
\end{tabular}

